\title{
MUSIK DALAM UPACARA ADAT POSUO
}

\author{
Ilham Watulea \\ Universitas Negeri Manado \\ e-mail : arulditry17@gmail.com \\ Diterima: 5 Agustus 2018. Disetujui : 10 November 2018. Dipublikasikan : 1 Desember 2018

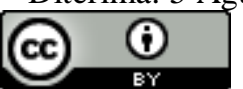 \\ (O2018 - DESKOVI Universitas Maarif Hasyim Latif. Ini adalah artikel dengan akses terbuka di \\ bawah lisensi CC BY 4.0 (https://creativecommons.org/licenses/by/4.0/)
}

\begin{abstract}
ABSTRAK
Musik merupakan salah satu aspek penting yang digunakan dalam berbagai upacara keagamaan dan budaya oleh masyarakat seperti upacara kelahiran, pernikahan, kematian dan upacara inisiasi, baik yang bersifat sakral maupun sekuler, termasuk dalam upacara adat posuo (pingitan). Upacara adat posuo yang merupakan sebuah upacara peralihan status dari wanita remaja menuju wanita dewasa pada masyarakat Tolandona-Buton Tengah. Dalam upacara ini, terdapat beberapa instrumen musik perkusi yang digunakan yang disajikan sebagai pengiring berbentuk instrumental yang dilakukan selama proses pelaksanaan upacara berlangsung. Sebagai asumsi awal adalah bahwa musik memiliki makna dan signifikansi dalam upacara ini, baik sebagai pengiring dan pembentuk ataupun pendukung suasana dalam upacara tersebut. Dalam fenomena ini, terdapat dua persoalan yang ingin dikaji yaitu pertama apa makna penyajian musik dalam pelaksanaan upacara adat posuo wolio pada masyarakat Tolandona-Buton Tengah dan kedua mengapa musik dihadirkan dalam upacara adat posuo wolio. Dalam studi ini, penulis menggunakan adalah pendekatan etnomusikologi dan cenderung pada kajian literatur dari beberapa dokumentasi dari foto dan video serta hasil penyelidikan yang pernah dilakukan. Sebagai kesimpulan bahwa musik sebagai cermin dari masyarakat memiliki hubungan dengan perilaku dan kegiatan manusia. Musik yang disajikan dalam suatu upacara keagamaan maupun upacara adat budaya memiliki signifikansi dalam pelaksanaan upacara tersebut baik sebagai pengiring atau pembentuk suasana maupun sebagai bagian dari ritual upacara tersebut. Meskipun dalam menginterpretasikan tidak terlepas dari konteks sosial budaya dan falsafah hidup masyarakat tersebut, artinya ini dapat berbeda pada setiap daerah. Bagaimana musik diperankan oleh kehidupan masyarakat serta bagaimana arti musik bagi satu masyarakat, pemahaman inilah yang mempengaruhi keberadaan dan guna musik bagi masyarakat.
\end{abstract}

Kata kunci: makna, musik, posuo wolio buton tengah-tolandona

\section{ABSTRACT}

Music is one of the important aspects used in various religious and cultural ceremonies by the community such as birth ceremonies, marriages, deaths and initiation ceremonies, both sacred and secular, including in the Posuo (pingitan) traditional ceremony. The Posuo traditional ceremony is a transitional ceremony of status from teenage women to adult women in Tolandona - Central Buton. In this ceremony, there are several percussion musical instruments used which are presented as accompaniments in the form of instrumental performed during the process of conducting the ceremony. As the initial assumption is that music has significance in this ceremony, both as an accompanist and support the atmosphere at the ceremony. In this phenomenon, there are two problems that want to be examined, first, what is the meaning of the presentation of music in the implementation of Posuo Wolio traditional ceremonies in the Tolandona Central Buton and secondly why music is presented in the Posuo Wolio traditional ceremony. In this study, the authors used the ethnomusicology approach and tended to review the literature from some documentation of photos and videos as well as the results of investigations that had been carried out. In conclusion, music as a mirror of society has a relationship with human behavior and activities. Music presented in a religious ceremony or traditional cultural ceremony has significance in the implementation of the ceremony both as an accompanist or forming an atmosphere and as part of the ritual ceremony. Although in interpreting it is inseparable from the socio-cultural context and life philosophy of the community, this means that it can vary in each region. How music is played by people's lives and how music means to one community, this understanding influences the existence and use of music for the community.

Keywords: meaning, music, posuo wolio buton tengah - tolandona 


\section{PENDAHULUAN}

Musik tradisional merupakan salah satu dari produk kebudayaan masyarakat yang hampir secara keseluruhan musik tradisional Indonesia dari sejak dahulu hingga sekarang masih digunakan sebagai sarana dalam upacara keagamaan maupun upacara adat budaya yang bersifat sakral maupun sekuler, hal ini menunjukkan sangat penting dalam kehidupan masyarakat Indonesia. Musik tradisional tidak menutup kemungkinan mengalami perubahan dan perkembangan dalam bentuk penyajiannya pada upacara keagamaan maupun upacara adat dalam suatu masyarakat. Hal ini dipengaruhi oleh kebudayaan itu sendiri yang bersifat dinamis serta pola pikir manusia yang terpengaruh oleh perkembangan pengetahuan dan teknologi. Dalam suatu kebudayaan masyarakat tidak terlepas dari upacara ritual yang terkait erat dengan siklus-siklus hidup masyarakat seperti kelahiran, pernikahan, inisiasi, hingga kematian. Setiap siklus merupakan masa peralihan yang diikuti dengan berpindahnya status, peran, tanggung jawab, maupun peristiwa-peristiwa penting dalam hidup, termasuk upacara adat Posuo sebagai daur hidup masyarakat di Tolandona-Buton Tengah.

Kabupaten Buton Tengah merupakan salah satu kabupaten di Provinsi Sulawesi Tenggara yang secara geografis masuk dalam wilayah daratan kabupaten Muna, namun secara administrasi pemerintahan masuk dalam pemerintahan kabupaten Buton yang baru di mekarkan pada tahun 2014 dan menjadi sebuah kabupaten yang baru. Masyarakat Buton Tengah memiliki beragam budaya dan tradisi upacara yang bersifat sakral maupun sekuler antara lain yaitu upacara bongka'atau, kande-kandea dan upacara adat posuo. Upacara adat posuo merupakan salah satu upacara adat bersifat sakral yang dipercaya oleh masyarakat Buton Tengah khususnya yang terdapat pada salah satu desa di kabupaten Buton Tengah yang masih melaksanakan tradisi ini yaitu masyarakat yang terletak di desa Tolandona. Posuo secara harfiah berarti pingitan. Upacara adat ini telah dikenal sebagai upacara adat sejak zaman kerajaan Buton yaitu abad ke-13 (1332 Masehi ) hingga pada abad awal abad ke-14 (1451 Masehi) berubah sistem pemerintahan menjadi sebuah kesultanan yang dipimpin oleh sultan Murhum Kaimuddin sebagai sultan pertama serta mengumumkan agama Islam sebagai agama yang dianut oleh masyarakat kerajaan dan masyarakat disekitrnya.

Dalam tradisi upacara adat posuo dikenal tiga jenis posuo yaitu pertama adalah posuo wolio yang merupakan posuo asli masyarakat wolio sejak kerajaan Buton berdiri, kedua adalah posuo johoro yang mendapat pengaruh Johor-Melayu dan yang ketiga adalah posuo arababu merupakan perpaduan dari kedua posuo tersebut yang diperkenalkan oleh Syekh Haji Abdul Ghaniyyu, salah seorang ulama besar Buton pada abad ke-19 atau sekiatar tahun 18241851. Dari ketiga bentuk upacara adat posuo ini memiliki tujuan yang sama yakni sebagai sebagai sebuah proses inisiasi bagi kaum wanita dari wanita remaja (kabuabua) menuju wanita dewasa (kalambe). Menurut tuturan La Ode Musrimin yaitu seorang budayawan serta sebagai parika (pemimpin para bhisa dalam upacara adat posuo) dalam pelaksanaannya oleh masyarakat Tolandona, upacara adat posuo wolio merupakan upacara adat yang dilaksanakan oleh masyarakat Tolandona-Buton Tengah.

Dalam pelaksanaan upacara adat posuo ini terdapat seorang bhisa (para pemimpin adat dalam upacara adat posuo) dan seorang parika (pemimpin para bhisa) sebagai pembimbing yang mengajarkan pengetahuan agama, moral, norma yang berlaku di masyarakat Tolandona-Buton Tengah serta pengetahuan dalam membina keluarga yang baik kepada para peserta posuo di masa depan dalam sebuah ruangan yang masyarakat setempat menyebutnya sou (ruangan belakang rumah) yang terisolasi oleh kehidupan sosial, selain itu hanya dapat berhubungan atau berkomunikasi dengan para bhisa dan parika yang telah diberikan tanggung jawab. Upacara ini biasanya dilaksanakan empat kali dalam satu tahun, yang dalam kepercayaan masyarakat setempat terdapat empat bulan yang baik dalam satu tahun untuk melaksanakan upacara adat posuo yaitu bulan Syahban, Dzulkhijah, Syafar dan Syawal, yang mana masyarakat Tolandona secara keseluruhan menganut agama Islam. Namun, seiring berjalannya waktu adanya perubahan dalam proses pelaksanaan yakni hal ini tergantung dari pihak keluarga yang memiliki nazar serta materi yang cukup, kemudian hal lainnya adalah terkait persiapan dari para peserta posuo itu sendiri yang disesuaikan dengan kegiatan liburan sekolah, dikarenakan dalam pelaksanaannya para peserta ini bisa mencapai puluhan orang.

Dalam tahapan pelaksanaan upacara adat ini terdapat penyajian musik yang disebut Gandana posuo oleh masyarakat setempat dengan beberapa instrumen musik perkusi seperti Mbulolo (Gong), Tawa-tawa (Gong yang berukuran sedang), Dengu-dengu (Kenong) dan instrumen gendang yang digunakan sebagai pengiring berbentuk instrumental selama proses pelaksanaan upacara ini. Dalam sejarah zaman dahulu yakni pada masa berdirinya kerajaan Buton, pelaksanaan upacara adat posuo yang menggunakan instrumen musik dilakukan oleh kaum yang berketurunan bangsawan namun seiring berjalannya waktu dan perkembangan dalam upacara adat posuo ini, terdapat pula masyarakat yang bukan merupakan keturunan bangsawan terlibat sebagai peserta dalam proses pelaksanaan upacara tersebut.

\section{PEMBAHASAN}

\section{Upacara adat posuo}

Istilah Posuo diambil dari kata "Po" dan "Suo, Po sebagai awalan kata yang mengandung makna "melakukan" atau "menjalankan" sedangkan 
“Suo" artinya ruang belakang rumah. Posuo secara harfiah adalah pingitan. Pelaksanaan tradisi upacara adat Posuo ini bertujuan sebagai proses inisiasi seorang wanita dari remaja (kabuabua) menuju dewasa (kalambe), serta guna mempersiapkan mentalnya dalam membina rumah tangga di masa depan. Upacara ini biasanya dilaksanakan selama delapan hari delapan malam dalam ruangan khusus yang oleh masyarakat setempat menyebutnya dengan Suo, meskipun terdapat beberapa kelompok masyarakat di Buton Tengah yang melakukan upacara ini dengan durasi waktu yang berbeda yakni ada yang melaksanakan dalam waktu satu minggu, lima hari, empat hari dengan berbagai pertimbangan dan atas kesepakatan musyawarah yang dilakukan oleh para bhisa, pemangku adat dan perwakilan para orang tua dari peserta posuo yaitu salah satu pertimbangan mengenai kemampuan fisik dari para peserta posuo, hal ini disebabkan dalam pelaksanaannya para peserta ini akan digembleng mental serta fisik mereka kemudian dijauhkan atau terisolasi dari masyarakat. Dalam studi antropologi telah diklasifikasikan beberapa tipe ritual yang berbeda-beda, salah satu diantaranya adalah upacara peralihan (rites of passage) di mana dalam upacara ini, orang tersebut akan dipisahkan dari masyarakat seluruhnya, kemudian untuk beberapa lama ia diisolasikan dan akhirnya ia dipersatukan lagi dengan masyarakat dalam sebuah kedudukan yang baru (Havilan, 1985, p. 207). Pada konteks upacara adat posuo wolio ini, para peserta terisolasi dari budaya di luar selama beberapa hari dalam pelaksanaan upacara adat ini.

I Wayan Senen mengemukakan bahwa upacara merupakan sebuah kegiatan keagamaan dan adat budaya yang terstruktur sebagai salah satu media untuk mendekatkan diri, memuja, menyembah, menghormat, memberi, memohon, atau mengungkapkan rasa syukur kepada objek yang di tuju. Dengan tujuan utama adalah mencapai moksa atau kebahagian sejati. Lebih lanjut dikatakan bahwa melalui pelaksanaan upacara tersebut, umat manusia yang beragama dapat mendayagunakan kepercayaan dan bhaktinya kepada Tuhan untuk membangun spiritualnya dan pada gilirannya sampai pada peningkatan keluhuran moral dan mental untuk menghadapi persoalan hidup di dunia. Diharapkan upacara tersebut dapat merubah perilaku manusia, misalnya kualitas moral meningkat, kesediaan untuk menolong orang meningkat, rasa kasih sayang terhadap alam lingkungan meningkat dan keteguhan iman dapat meningkat. Berdasarkan pengertian ini, maka dalam upacara adat posuo wolio yang dilakukan pada masyarakat Tolandona merupakan sebuah upacara sebagai tujuan untuk dapat mencapai kehidupan seorang wanita saat berumah tangga serta bahagia di masa depan. (Senen, 2015, pp. 17-19)

Kehadiran Gandana Posuo dalam upacara adat Posuo Wolio pada masyarakat Tolandona-Buton Tengah
Sesuatu yang dibuat atau dihadirkan oleh manusia kemungkinan memiliki kontribusi bagi si pembuat, hal ini sebagai dasar dari pendefinisian kebudayaan. Kebudayaan sejatinya adalah hasil dari karya manusia yang dibuat sebagai kebutuhan dan bentuk ekspresi diri, baik individu ataupun kelompok terhadap sesuatu yang di tuju. Contoh sederhananya adalah karya musik yang dibuat oleh manusia, di sisi lain sebagai kebutuhan bagi manusia itu sendiri secara individu maupun kelompok juga sebagai sarana ekspresi terhadap sesuatu yang di tuju (objek) yakni Tuhan, Manusia, dan alam.

Seperti halnya masyarakat di seluruh dunia yang memiliki budaya yang unik, masyarakat Tolandona-Buton Tengah juga memiliki ragam budaya dengan berbagai unsurnya. Sebagai hasil kebudayaan pada masyarakat Tolandona yaitu pelaksanaan upacara adat posuo wolio yang di dalam prosesinya dihadirkan musik berbentuk instrumental, tentunya memiliki signifikansi dalam upacara adat tersebut, bagi para peserta posuo dan masyarakat sekitar. Meskipun demikian, signifikansi kehadiran musik dalam upacara adat ini memiliki perbedaan dalam konteks upacara yang lainnya misalnya yang terdapat dalam upacara bongka'atau dan kandekandea. Penyajian musik dalam sebuah upacara baik keagamaan maupun budaya yang terdapat dalam masyarakat di Indonesia tentunya memiliki arti penting dalam proses pelaksanaan sebuah upacara yang sedang berlangsung. I ketut Donder dalam bukunya "Esensi Bunyi Gamelan dalam Prosesi Ritual Hindu" (Donder, 2005, pp. 121-127) menjelaskan bahwa esensi bunyi gamelan yang dihadirkan dalam konteks prosesi ritual Hindu secara universal yaitu menambah suasana yang religius, magis dan sakral. Kemudian I Wayan Senen menjelaskan bahwa penyajian bunyi-bunyian atau penyajian musik sangat dibutuhkan dan memegang peranan penting dalam upacara keagamaan dan adat budaya di Indoneisa, baik sebagai pengiring upacara, maupun pendukung (pembentuk) suasana dalam upacara, lebih lanjut dituliskan bahwa kehadiran bunyi-bunyian ritual dalam upacara di Bali sangat esensial. Secara hakekat, bunyi-bunyian itu digunakan untuk menunjukkan rasa bhakti (pelayanan, penghormatan), sebagai perwujudan suatu kerja atau kewajiban (karma), sebagai aplikasi pengetahuan (jnana) para penyelenggara dan pelaksana upacara, dan sebagai perwujudan doa dan rasa syukur kepada Tuhan. Dengan melihat pada konteks pada pelaksanaan upacara adat posuo tentunya penyajian musik yang dihadirkan tidak begitu saja muncul dalam pemahaman masyarakat Tolandona sebagai pembentukan suasana yang dianggap sakral dan religius, tentunya memiliki tujuan dan makna yang lainnya. Namun untuk hal ini masih menjadi pertanyaan yang kiranya dibutuhkan sebuah riset lapangan untuk dapat mendeskripsikannya secara sistematis dan ilmiah, kemudian ini untuk menghindari pemaknaan yang berbeda dari 
interpretasi dari dari beberapa referensi dan terhadap pengetahuan. (Senen, 2015, p. 14)

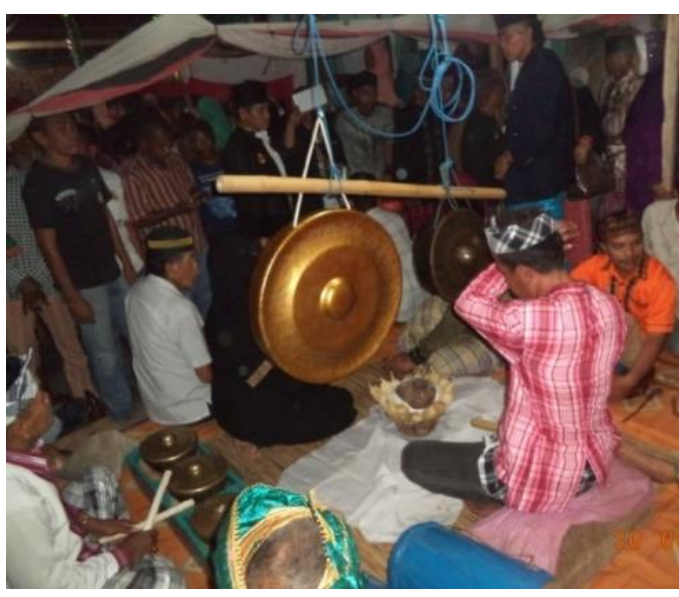

Gambar 1. Upacara adat Posuo ( Sumber : Foto Pribadi )

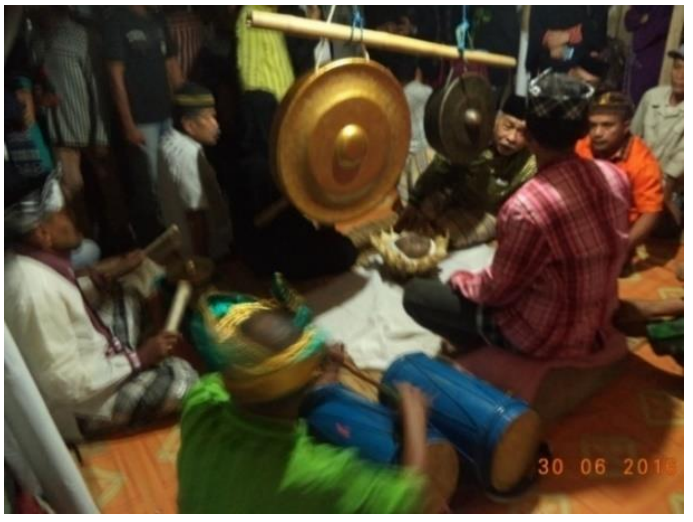

Gambar 2.Upacara adat Posuo ( Sumber : Foto Pribadi )

\section{Makna musik gandana posuo dalam upacara adat posuo wolio pada masyarakat Tolandona-Buton Tengah}

Setiap masyarakat memiliki budaya bermusik. Musik memiliki hubungan dengan hampir seluruh perilaku dan kegiatan hidup manusia dalam suatu masyarakat. Makna musik dalam masyarakat berbeda-beda dalam setiap daerah hal ini dipengaruhi oleh perilaku, pemahaman budaya, pandangan hidup dan falsasah masyarakat tersebut. Hazrat Inayat Khan dalam bukunya "Dimensi Mistik Musik dan Bunyi". Terjemahan Subagijono dan Fungky Kusnaedy Timur (Khan, 2002, p. 13), mengatakan bahwa musik oriental secara keseluruhan didasarkan pada fondasi filsafat dan ruhaniah. Apa yang dikemukakan oleh Inayat Khan bahwa musik yang terdapat dalam suatu masyarakat memiliki fondasi falsafah dan sifat ruhaniah dari masyarakat, artinya perwujudan sebuah makna musik tercermin dari falsafah dan pandangan hidup masyarakat tersebut sebagai pemiliknya. Sebagai contoh dalam pertunjukan sakral Tari Bedaya yang merupakan salah satu jenis tarian putri keraton
Jawa (Surakarta dan Yogyakarta) yang tidak terlepas dari ekspresi keadaan sosial yang menceritakan sebuah percintaan atau peperangan pada konteks saat itu. Perry Rumengan dalam artikelnya yang berjudul "Musik Sebagai Pintu Masuk Memahami Budaya dan Kondisi Masyarakat" (Rumengan, n.d.) menuliskan bahwa seluruh latar belakang kontekstual musik dapat ditemukan, baik dalam elemen atau sistem pemberdayaan elemen, perilaku musikal. Lebih lanjut dikatakan dalam kerja pengkajian kita harus dapat menelusuri keterkaitan antara teks dan konteks atau elemen musikal dan aspek ekstra musikal yang kesemuanya harus disesuaikan dengan pandangan masyarakat sebagai pelaku dan pemilik musik tersebut, karena setiap masyarakat memiliki estetika musikalnya sendiri-sendiri, baik jenis musik dan perilaku penyajiannya sangat dipengaruhi oleh kondisi kehidupan zamannya. Jelaslah, bahwa konsep musik pada setiap kebudayaan dapat saja berbeda. Hal ini tidak terlepas dari apa yang dikatakan oleh Shin Nakagawa dalam bukunya "Musik dan Kosmos Sebuah Pengantar Etnomusikologi" (Nakagawa, 2000, p. 6)bahwa musik dianggap sebagai cerminan sistem sosial atau sebaliknya, yaitu mengenai aspek teks yakni kejadian akustik dan konteks adalah suasana, yaitu keadaan yang dibentuk oleh masyarakat pendukung musik tersebut. Kemudian John Sheperd, seperti yang dikutip oleh Ivo Supicic (1987 : 274) menyatakan bahwa "the meaning of music is somehow located in its function as social symbol" [makna musik terletak pada fungsinya sebagai simbol sosial]. Jika dilihat dari apa yang dikatakan oleh John Sheperd, Secara tidak langsung, setidaknya konteks saat ini dapat dikatakan bahwa musik memiliki makna yang merepresentasikan masyarakat Tolandona sebagai masyarakat yang masih memegang teguh ajaran Islam dan adat istiadat yang dimiliki sebagai siklus kehidupan.

Dalam sebuah artikel Kofi Poku QuanBaffour berjudul Ritual Songs for Girls' Nubility Rites at Bono Takyiman, Ghana, (Quan-Baffour, 2014) dikatakan bahwa musik atau nyanyian-nyanyian ritual inisiasi bagi kaum wanita pada masyarakat Bono Takyiman memiliki arti yang signifikan sebagai sebuah sugesti yang bersifat sakral bagi para wanita yang melakukan proses pelaksanaan ritus inisiasi, yang tidak hanya bersifat sosio-religius tetapi juga bersifat edukatif bagi masyarakat sekitar. Pada konteks pelaksanaan upacara adat posuo yang dilakukan oleh masyarakat Tolandona, kiranya penjelasan di atas memiliki sebuah relavansi dalam artian adanya persamaan subjek dalam pelaksanaan upacara atau ritual inisiasi bagi kaum wanita meskipun memiliki perbedaan nilai estetis yang dipengaruhi oleh keadaan geografis, latar belakang budaya dan kepercayaan masyarakatnya.

\section{KESIMPULAN}


Musik sebagian cermin kehidupan dari kelompok masyarakat. Musik yang dihadirkan dalam suatu upacara keagamaan maupun upacara adat budaya memiliki signifikansi dalam pelaksanaan upacara tersebut baik sebagai pengiring atau juga yang membentuk suasana maupun sebagai bagian ritual dalam suatu upacara yang dilakukan. Meskipun dalam menginterpretasikannya tidak terlepas dari konteks sosial budaya dan falsafah hidup masyarakat tersebut, artinya ini dapat berbeda pada setiap daerah. Bagaimana musik diperankan oleh kehidupan masyarakat serta bagaimana arti musik bagi satu masyarakat, pemahaman inilah yang mempengaruhi keberadaan dan guna musik bagi masyarakat dan dalam konteks pada masyarakat upacara adat Posuo di tolandona, mengadung makna merepresentasikan masyarakat yang masih memegang teguh ajaran islam sebagai bagian yang tak terpisahkan dalam adat istiadat yang dimiliki.

\section{DAFTAR PUSTAKA}

Donder, I. ketut. (2005). Esensi Bunyi Gamelan dalam Prosesi Ritual Hindu Perspektif Filosofis, Teologis, Psikologis, Sosiologis, dan Sains. Surabaya: Paramita.

Havilan, W. A. (1985). Antropologi Terj. R.G. Soekadijo Jilid 2. Jakarta: Erlangga.

Husein, A., \& dkk. (1985). Kamus Wolio-Indonesia.
Jakarta: Pusat Pembinaan dan Pengembangan Bahasa Departemen Pendidikan dan Kebudayaan.

Khan, H. I. (2002). Dimensi Mistik Musik dan Bunyi. Yogyakarta: Pustakan Sufi.

Mariana, F. (2017). Upacara Adat Posuo Sebagai Media Komunikasi Pendidikan Informal Perempuan Wolio di Kota Bau Bau Makassar. Universitas Hasanuddin.

Nakagawa, S. (2000). Musik dan Kosmos Sebuah Pengantar Etnomusikologi. Jakarta: Yayasan Obor Indonesia.

Ode, H. La, Tadjir, M. R., \& Abidin, H. M. (2005). Upacara Adat Posuo. Bau-Bau: Dinas Pariwisata Seni dan Budaya.

Ode, K. La. (2011). Makna Pertunjukan Lagu Maludhu Dalam Upacara Pernikahan Masyarakat Kulisusu Buton Utara. Institut Seni Indonesia Yogyakarta.

Quan-Baffour, K. P. (2014). Ritual Song's For Girls' Nubility Rites at Bono Takyiman, Ghana. Muziki : Journal of Music Research in Africa, 6(1), 26-35.

Rumengan, P. (n.d.). Musik Sebagai Pintu Masuk Memahami Budaya dan Kondisi Masyarakat. Universitas Hasanuddin.

Senen, I. W. (2015). Bunyi-bunyian Dalam Upacara Keagamaan Hindu di Bali. Yogyakarta: Institute Seni Indonesia Yogyakarta. 
Ilham Watulea / DESKOVI : Art and Design Journal, Vol. 1, No.1, Desember 2018, 23-28

(Halaman ini sengaja dikosongkan) 